\title{
Adrenal cysts-a report of four cases including one with bilateral involvement
}

\author{
Fernandes $\mathbf{G}^{1}$, Chaudhari $\mathbf{J}^{2}$, Shah $\mathbf{N}^{3}$, Gupta $\mathrm{A}^{4}$ \\ ${ }^{1}$ Dr. Gwendolyn Fernandes, Associate Professor, Department of Pathology, ${ }^{2}$ Dr. Jayashri Chaudhari, Assistant Professor, \\ Department of Pathology, ${ }^{3}$ Dr. Nalini Shah, Professor \& Head, Department of Endocrinology, ${ }^{4}$ Dr. Akriti Gupta, \\ Ex-Fellow in Uropathology, Department of Pathology; all authors are affiliated with Seth G. S. Medical College \& KEM \\ Hospital, Parel, Mumbai, Maharashtra, India.
}

Address for Correspondence: Dr. Gwendolyn Fernandes, C- 802, Swayam, Poonam Gardens, Mira Road, Thane, Maharashtra. E-mail: drgwenfern@yahoo.co.in; drgwenfern@gmail.com

\begin{abstract}
Adrenal cystic lesions are rare entities. Four types of cystic lesions of the adrenal gland have been described in literature namely, epithelial cysts, endothelial cysts, pseudocysts and parasitic cysts. Tumors of the adrenal gland, both benign and malignant may also show cystic change and have to be considered in the differential diagnosis of cystic lesions of the adrenal gland. Lymphangioendotheliomas, though common at other sites, are unusual in the adrenal glands and bilateral involvement is extremely rare. We present four cases of adrenal cysts, two cases of lymphangioendothelial cysts and two cases of pseudocysts from 108 adrenalectomy specimens received over 5 years. Two of these had hypertension which resolved after surgery. All of our cases did well postoperatively. Prognosis of these benign cysts is excellent and the patients are disease-free after surgery.
\end{abstract}

Keywords: Adrenal cyst, Lymphangioendothelial, Pseudocyst

\section{Introduction}

Adrenal cystic lesions are rare with an incidence of $0.06 \%$ in general population. [1, 2]. Various types of cystic lesions of the adrenal gland have been described and have been classified into epithelial cysts, endothelial cysts, pseudocysts and parasitic cysts [1]. Tumors of the adrenal gland, both benign and malignant can also show cystic change and have to be considered in the differential diagnosis of cystic lesions of the adrenal gland [2]. Lymphangioendotheliomas though common at other sites, are unusual in the adrenal glands and bilateral involvement is extremely rare $[1,3]$.

We present four cases of adrenal cysts, one of which was bilateral and three unilateral. Two of the cases including one with bilateral involvement, were classified as lymphangioendothelial cysts and two were pseudocysts.

Case-1: A 48 year old female presented with complains of pain in abdomen since one month, which was dull aching and located in the periumbilical region. Her basal cortisol was $12.8 \mu \mathrm{g} / \mathrm{dl}$, ACTH and catecolamine levels were normal. CT scan showed bilateral, non- enhancing, cystic adrenal masses with foci of calcification. (Fig1a) A right adrenalectomy was done and we received the adrenal gland entirely as a multiloculated cystic mass measuring $7 \times 4 \times 3 \mathrm{~cm}$ and weighing 30 gms. (Fig 2a) These cysts varied in size from $2 \mathrm{~mm}$ to $8 \mathrm{~mm}$. Clear fluid was seen in the cysts. Normal yellowish brown adrenal tissue was seen between the cysts. Microscopy showed adrenal tissue replaced by multiple cysts of varying sizes. The lining epithelium was focally present at places but mostly denuded and the cysts contained eosinophilic fluid material. Focal calcification was also seen in the cyst wall. (Fig 3a, 3b) Cyst lining wherever present

Manuscript received $27^{\text {th }}$ August 2016

Reviewed: $10^{\text {th }}$ September 2016

Author Corrected: $20^{\text {th }}$ September 2016

Accepted for Publication $7^{\text {th }}$ October 2016 


\section{Case Report}

was positive for CD34 (Fig 3c), CD 31 and negative for cytokeratin. A diagnosis of bilateral lymphangioendothelial cyst was made. Her postoperative course was uneventful and she was discharged on the fourth postoperative day.
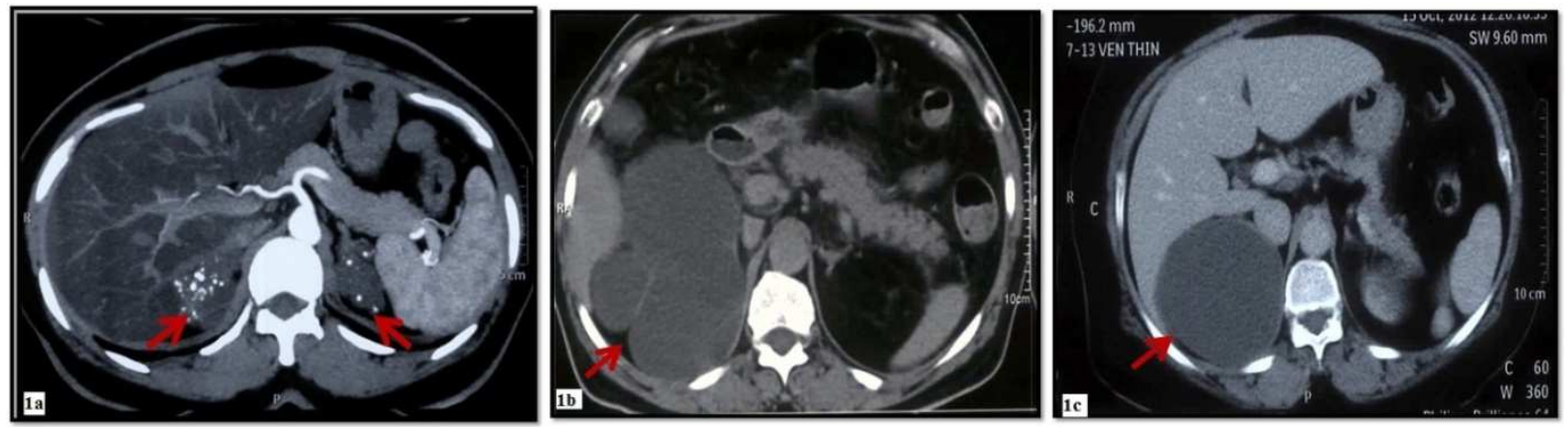

Figure-1: CT scan pictures

1a: Case 1.-CT scan showed bilateral non enhancing cystic adrenal masses with foci of calcification

1b: Case 2- CT scan of abdomen revealed right side, single, huge, multiloculated hypodense cystic lesion measuring $12 \mathrm{x}$ $10 \times 10 \mathrm{~cm}$

1c: Case 4-CT scan showed multiple gall stones and a cyst in the right adrenal measuring 8x 5x $8 \mathrm{~cm}$ in size

Case-2: A 60 year old male presented with abdominal pain and vomiting since 2 years. He had a history of hypertension since 1 year. Serum cortisol, ACTH, and catecholamine levels were within normal limits. CT scan of abdomen revealed a right-sided single huge, multiloculated hypodense cystic lesion measuring $12 \mathrm{x} 10 \mathrm{x} 10 \mathrm{~cm}$. (Fig 1b) A right adrenalectomy was done and the specimen measured 10x 9.5 x $8.5 \mathrm{~cm}$, weighing 70 gms and was composed of multiloculated cysts varying in size from $7 \mathrm{~mm}$ to $1 \mathrm{~cm}$. Microscopy revealed adrenal tissue with multiloculated cysts lined by flattened endothelial cells. The cysts contained eosinophilic material. Foci of calcification and fibrosis were also seen. (Fig 3d, 3e) The CD 34 and CD 31 stain was strongly positive in the lining of the cyst wall. (Fig3f) Cytokeratin was negative. A diagnosis of Lymphangioendothelial cyst of the adrenal gland was made. The hypertension resolved after surgery.
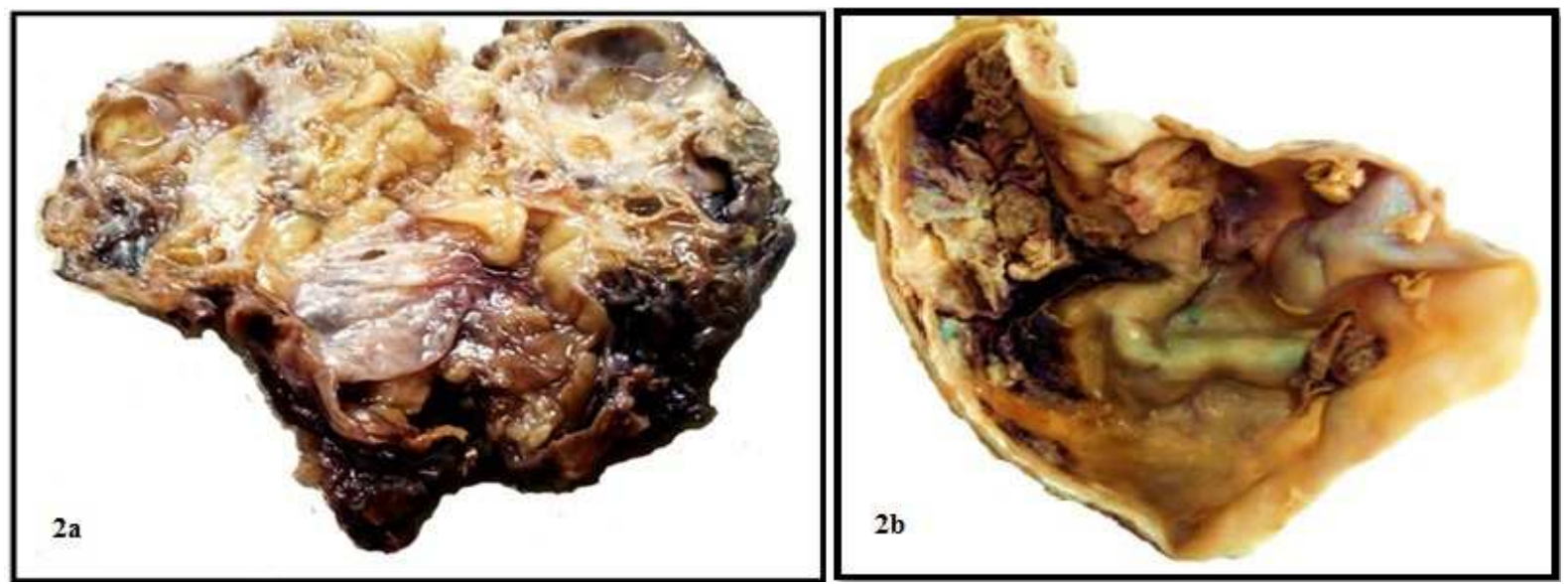

Figure-2: Gross

2a: Case 1- Multiloculated cystic adrenal mass

2b: Case 4 - Large uniloculated cyst with smooth inner surface

Case-3: A 51 year old female with pain in the right hypochondrium and breathlessness since 3-4 months. CT scan of the abdomen showed a well defined $6.7 \times 6.5 \times 6 \mathrm{~cm}$ cystic mass in the right adrenal gland. A clinical diagnosis of adrenal cyst or hydatid cyst was available. We received a cystic structure measuring 8 x $5 \times 3 \mathrm{~cm}$ with adrenal tissue identified at 
the periphery. The cyst was uniloculated and contained hemorrhagic necrotic material. Microscopy revealed a cystic structure composed of fibro-collagenous tissue. The cyst had no lining seen despite extensive sections studied. The cyst was however lined by hemorrhagic, necrotic material and showed extensive calcification in the wall. A diagnosis of pseudocyst of the adrenal gland was made.

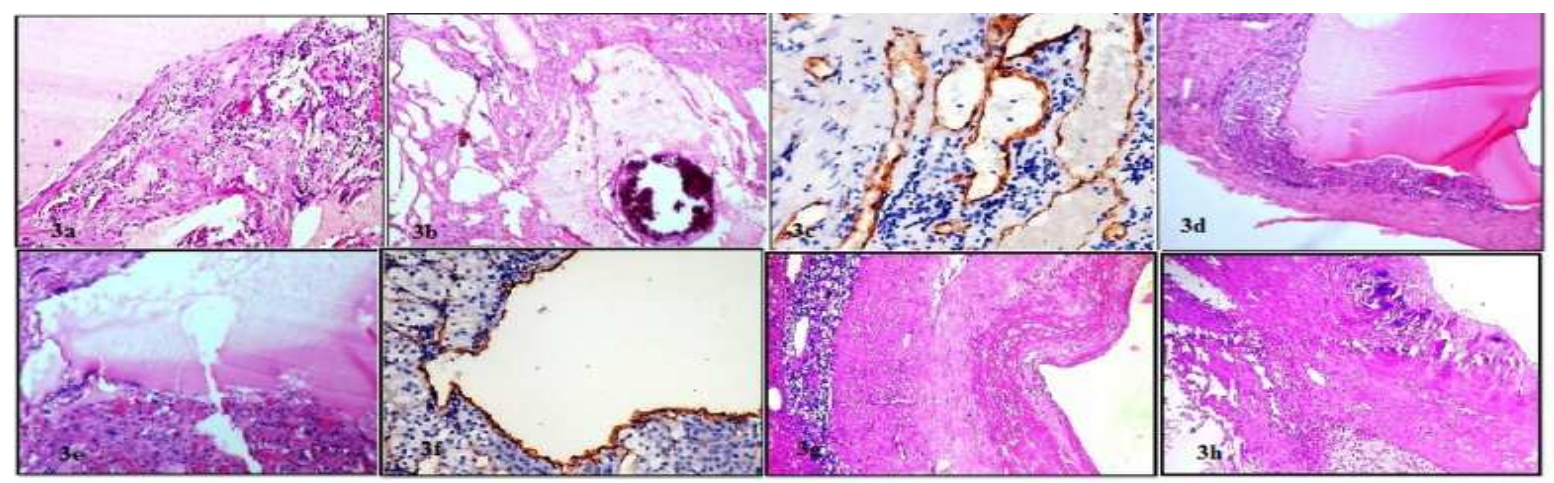

Figure-3: Microscopy

3a: Case 1- Cysts contained eosinophilic fluid material

3b: Case 1- Focal calcification was seen in the cyst wall

3c: Case1-Cyst lining positive for CD34

3d: Case 2- Cysts lined by flattened endothelial cells \& contained eosiniphilic material

3e: Case 2- Adrenal tissue seen in the wall

3f: Case 2-Cyst lining positive for CD34

3g: Case 4-Cyst wall made up of dense fibrous tissue

3h: Case 4- Calcification and adrenocortical clear cells were seen

Case-4: A 50 year old female presented with pain in abdomen since 3 months. CT scan showed multiple gall stones and a cyst in the right adrenal gland measuring $8 \times 8 \times 5 \mathrm{~cm}$ in size. (Fig 1c) Her basal cortisol was raised. ACTH and catecolamine levels were within normal limits. She was hypertensive since one year. We received an adrenalectomy and cholecystectomy specimens. The adrenalectomy specimen was composed of a large cyst measuring $7.5 \mathrm{~cm}$ in diameter and showed adrenal tissue in the wall. The inner surface was smooth and yellow in color. (Fig 2b) Microscopy revealed the cyst wall made up of dense fibrous tissue with calcification. Adrenocortical clear cells were seen focally in the cyst wall. No lining epithelium to the cyst wall was seen despite extensive sections studied. (Fig 3 g, $3 \mathrm{~h}$ ) A diagnosis of pseudocyst of adrenal gland was made. The hypertension resolved after surgery.

\section{Discussion}

We received total 108 adrenalectomy specimens over a five 5 year period at our institute. Amongst these, four cases of adrenal cysts were received and one of them showed bilateral involvement. Cystic lesions of the adrenal gland though uncommon, should be considered in the differential diagnosis of abdominal mass [4].

Ninety five percent of lymphangiomas are located in the neck or axilla and the other $5 \%$ are located in abdominal cavity including mesentery of small intestine, omentum, mesocolon and retroperitonium [5]. Adrenal lymphangiomas are relatively rare with an incidence of $0.06 \%$ in general population. Lymphangiomas are seen at all ages with peak in $3^{\text {rd }}$ to $6^{\text {th }}$ decade [5]. All our cases are in the $4^{\text {th }}$ to $5^{\text {th }}$ decade of life. Three of our patients were female and one male. Adrenal cysts are often discovered incidentally but large cysts can present with abdominal pain, hemorrhage, rupture, mass lesion, arterial hypertension especially in functional cysts etc. [6] All four of our cases presented with abdominal pain of varying duration. Hypertension was seen in 2 of our patients and cortisol level was raised in one of them and her hypertension resolved after surgery. 
The pathogenesis of the cystic lymphangioendotheliomas is not well known. It is believed that these lesions occur from continued growth of ectopic or malformed lymphatic tissue or represent a hyperplastic reaction to inflammation or a lymphatic hamartomas or blockage of draining lymphatics with proximal dilatation of lymphatic system [5]. Imaging can pick up the cystic nature of these cysts as well as calcification in the cyst wall.

Summary of the four cases.

\begin{tabular}{|c|c|c|c|c|}
\hline & Case 1 & Case 2 & Case 3 & Case 4 \\
\hline History & 48 year, female & $\begin{array}{l}60 \text { year male, } \\
\text { hypertensive \& diabetic } \\
\text { since } 1 \text { year }\end{array}$ & 51 year female & $\begin{array}{l}50 \text { year female, } \\
\text { known diabetic and } \\
\text { hypertensive }\end{array}$ \\
\hline $\begin{array}{l}\text { Clinical } \\
\text { presentatio } \\
\text { n }\end{array}$ & $\begin{array}{l}\text { - dull ache in periumbilical } \\
\text { region since } 1 \text { month } \\
\text { - no abnormality on } \\
\text { abdominal palpation }\end{array}$ & $\begin{array}{l}\text { - acute abdominal pain, } \\
\text { vomiting since } 2 \text { years } \\
\text { - tenderness }\end{array}$ & $\begin{array}{l}\text { - pain in the } \\
\text { right } \\
\text { hypochondrium } \\
\text { and } \\
\text { breathlessness } \\
\text { since 3-4 months } \\
\text { - No abnormality }\end{array}$ & $\begin{array}{l}\text { - diffuse pain in } \\
\text { abdomen since } 3 \\
\text { month } \\
\text { - tenderness }\end{array}$ \\
\hline $\begin{array}{l}\text { Laboratory } \\
\text { investigatio } \\
\text { ns }\end{array}$ & $\begin{array}{l}\text { Basal cortisol-normal } \\
\text { ACTH-normal } \\
\text { Catecolamines-normal }\end{array}$ & $\begin{array}{l}\text { Basal cortisol-normal } \\
\text { ACTH-normal } \\
\text { Catecolamines-normal }\end{array}$ & Not available & $\begin{array}{l}\text { Basal cortisol-raised } \\
\text { ACTH-normal } \\
\text { Catecolamines- } \\
\text { normal }\end{array}$ \\
\hline $\begin{array}{l}\text { Imaging- } \\
\text { CT scan }\end{array}$ & $\begin{array}{l}\text { multiple cysts of both } \\
\text { adrenal glands with } \\
\text { peripheral rim of } \\
\text { calcification }\end{array}$ & $\begin{array}{l}\text { Right sided single huge, } \\
\text { multiloculated } \\
\text { hypodense cystic lesion } \\
\text { measuring } 12 \times 10 \times 10 \mathrm{~cm}\end{array}$ & $\begin{array}{l}\text { a well defined } 6.7 \\
\times 6.5 \times 6 \mathrm{~cm} \text { cystic } \\
\text { mass in the right } \\
\text { adrenal gland }\end{array}$ & $\begin{array}{l}\text { Right sided single } \\
\text { uniloculated lesion in } \\
\text { the suprarenal region } \\
8 \times .5 \times 8 \mathrm{~cm}\end{array}$ \\
\hline $\begin{array}{l}\text { Gross } \\
\text { Pathology }\end{array}$ & $\begin{array}{l}\text { - weight: } 30 \mathrm{~g} \\
\text { - size }: 7 \times 4 \times 3 \mathrm{~cm} \\
\text { - multiple cysts, size range } \\
0.2-0.8 \mathrm{~cm} \text { cysts } \\
\text { - contained whitish clear } \\
\text { fluid } \\
\text { - adrenal tissue identified } \\
\text { in the septae of the cyst }\end{array}$ & $\begin{array}{l}\text { - weight } 70 \mathrm{gm} \\
\text { - size: } 10 \mathrm{x} 8.5 \mathrm{x} 9.5 \mathrm{~cm} \\
\text { - multiloculated cyst, } \\
\text { locule size ranged from } \\
7.3 \text { to } 7 \text { to } 1 \mathrm{x} 1 \mathrm{~cm} \text {. Inner } \\
\text { surface was smooth with } \\
\text { yellowish areas } \\
\text { - Adrenal gland tissue } \\
\text { seen in the wall of cyst }\end{array}$ & $\begin{array}{l}\text { - size: } 8 \times 5 \times 3 \\
\mathrm{~cm} \\
\text { - cyst which was } \\
\text { uniloculated } \\
\text { - contained } \\
\text { hemorrhagic } \\
\text { necrotic material. } \\
\text { - adrenal tissue } \\
\text { identified in the } \\
\text { cyst wall }\end{array}$ & $\begin{array}{l}\text { - size: } 7.5 \mathrm{~cm} \\
\text { diameter } \\
\text { - uniloculated cyst. } \\
\text { Inner surface was } \\
\text { smooth with yellow } \\
\text { areas. }\end{array}$ \\
\hline $\begin{array}{l}\text { Histopathol } \\
\text { gy }\end{array}$ & $\begin{array}{l}\text { - multiple cysts lined by } \\
\text { flattened endothelial cells, } \\
\text { - septae show muscle } \\
\text { fibers, lymphoid } \\
\text { aggregates \& calcification. } \\
\text { - eosinophilic material in } \\
\text { their lumina. } \\
\text { - adrenal cortical cells in } \\
\text { the septae of cyst. }\end{array}$ & $\begin{array}{l}\text { - multioculated cystic } \\
\text { structure with cysts lined } \\
\text { by flattened endothelium. } \\
\text { - Wall of cyst show focal } \\
\text { fibrosis, calcification and } \\
\text { lymphocytes. } \\
\text { - eosinophilic material in } \\
\text { their luminal, } \\
\text { - adrenal cortical cells in } \\
\text { the septae of cyst seen }\end{array}$ & $\begin{array}{l}\text { a cystic structure } \\
\text { composed of } \\
\text { fibrocollagenous } \\
\text { tissue lined by } \\
\text { hemorrhagic } \\
\text { necrotic material } \\
\text { - no lining } \\
\text { epithelium seen } \\
\text { and extensive } \\
\text { calcification } \\
\text { - adrenal cortical } \\
\text { cells in the wall } \\
\end{array}$ & $\begin{array}{l}\text { •cyst lined by thick } \\
\text { fibrous tissue. } \\
\text { •absence of lining } \\
\text { epithelium Wall } \\
\text { shows calcification } \\
\text { •adrenal cortical } \\
\text { tissue within the wall }\end{array}$ \\
\hline $\begin{array}{l}\text { Immunohist } \\
\text { ochemistry }\end{array}$ & $\begin{array}{l}\text { CD } 34 \text { positive } \\
\text { CK negative }\end{array}$ & $\begin{array}{l}\text { CD } 34 \text { positive } \\
\text { CK negative }\end{array}$ & - & - \\
\hline Diagnosis & $\begin{array}{l}\text { Bilateral } \\
\text { lymphangioendothelial } \\
\text { cyst of the adrenal glands }\end{array}$ & $\begin{array}{l}\text { Lymphangioendothelial } \\
\text { cyst of the adrenal } \\
\text { gland }\end{array}$ & $\begin{array}{l}\text { Pseudocyst of } \\
\text { the adrenal } \\
\text { gland }\end{array}$ & $\begin{array}{l}\text { Pseudocyst of the } \\
\text { adrenal gland }\end{array}$ \\
\hline
\end{tabular}

Adrenal cysts are classified into 4 types, endothelial cysts [45\%], pseudocysts 39\%, epithelial cysts (9\%) and parasitic cysts (7\%). Endothelial cysts can be divided into two types, angiomatous and lymphangiomatous [4] True vascular endothelial cysts (hemangiomas) are rare entities [4]. 
Adrenal cystic lymphangioendotheliomas are thin walled multiloculated cystic lesions with clear to brown colored fluid. These cysts are lined by flattened endothelial cells on microscopy. Immunohistochemistry using antibody to CD $31, \mathrm{CD}$ 34 and factor VIII confirm the endothelial lining of the cyst. [1] D2-40 is a specific marker for the lymphatic origin of the cyst wall and co expression of CD 34, CD31, D2-40 and factor VIII related antigen confirms its lymphatic origin. Both our cases of multiloculated cysts of adrenal showed positivity for CD 31, CD 34 and negativity for cytokeratin. D2-40 was not available at our institute. On the basis of light microscopy and CD 31 and CD 34 positivity and cytokeratin negativity; our multiloculated cystic lesions were labeled as lymphangioendothelial cysts.

Psedocysts are the commonest type of adrenal cysts, and are unilocular thick walled cysts and are devoid of epithelium and they can be calcified or even ossified. They can result from hemorrhage into the adrenal gland due to trauma, toxins, infectious process and tumor [5].

Epithelial cysts of adrenal are cysts lined by epithelium and cyst wall lining is positive for cytokeratin. They could represent cystic adenomas [4].

All our patients had surgical removal of the adrenal glands done, and postoperative period was uneventful. Two patients, one with lymphangioendothelial and one with pseudocyst had hypertension which resolved post surgery. Current treatment recommendations state that small asymptomatic lesions be observed while large complicated cysts be excised.[6] Since cystic lesions of adrenal are a heterogenous group of lesion and can even include malignancies with cystic degeneration, a thorough histopathological examination and immunohistochemistry is essential for diagnosis. Prognosis of these non-malignant cysts is excellent and the patients are disease- free after surgery.

\section{Funding: Nil, Conflict of interest: None. \\ Permission of IRB: Yes}

\section{References}

1. Joliat GR, Melloul, Djafarrian R, Schmidt S, Fontanella S, Yan P, Demartines $\mathrm{N}$ and Halkic N. Cystic lymphangioma of the adrenal gland: report of a case and review of the literature. World Journal of Surgical Oncology 2015 13:58.

2. Zhao M, Gu Q, Li C, Yu J, Qi H. Cystic lymphangioma of adrenal gland: a clinicopathological study of 3 cases and review of literature. Int J Clin Exp Pathol. 2014 Jul 15;7(8):5051-6.

3. Jung HI, Ahn T, Son MW, Kim Z, Bae SH, Lee MS, Kim $\mathrm{CH}$, Cho HD. Adrenal lymphangioma masquerading as a pancreatic tail cyst. World J Gastroenterol. 2014 Sep 28;20(36):13195-9.
4. Davenport M, Pollard K, Smith SE, MacMahon MJ. Adrenal cysts--report, review and classification. Postgrad Med J. 1988 Jan;64(747):71-3.

5. Faten Hadj Kacem, Mouna Ammar, Ayman Maalej, Nesrine Cheikrouhou, Nadia Charfi \& Mohamed Abid. A cystic lesion of the adrenal gland mimicking hydatid cyst. Endocrine Abstracts 2015; 37 EP1239

6. Ujam Atheer B. Peters Christopher J, Tadrous Paul J., Webster John Jeff, Steer Keith, and Martinez-Isla Alberto. Adrenal pseudocyst: Diagnosis and laparoscopic management - A case report. Int J Surg Case Rep. 2011; 2(8): 306-308.

\section{How to cite this article?}

Fernandes G, Chaudhari J, Shah N, Gupta A. Adrenal cysts-a report of four cases including one with bilateral involvement.Int J Med Res Rev 2016;4(11):1970-1974.doi:10.17511/ijmrr. 2016.i11.11. 